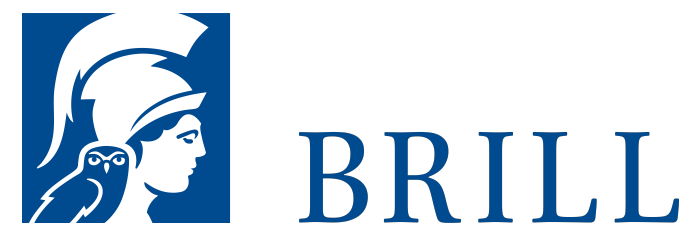

\title{
Der verleugnete Rechtsstaat
}

Anmerkungen zur Kultur des Todes in Europa. 2. Auflage

Author: Manfred Spieker

Seit 30 Jahren schleicht die Kultur des Todes durch

Deutschland. Sie gibt vor, Leben zu schützen, die

Menschenwürde zu respektieren und die Selbstbestimmung zu fördern. In Wirklichkeit ist sie angetreten, Leben zu vernichten, die Menschenwürde zu relativieren und Ungeborene sowie Sterbende, die der Gesellschaft zur Last fallen, zu entsorgen. Kultur des Todes ist ein sperriger Begriff. Sie hat nichts zu tun mit der ars moriendi, jener Kunst des Sterbens eines reifen Menschen, der dem Tod ebenso bewusst wie gelassen entgegen geht. Sie hat auch nichts zu tun mit Mord und Tot-schlag. Kultur des Todes meint vielmehr ein Verhalten einerseits und gesellschaftliche sowie rechtliche Strukturen andererseits, die bestrebt sind, das Töten gesellschaftsfähig zu machen, indem es als medizinische Dienstleistung oder als Sozialhilfe getarnt wird. Sie bedient sich vieler Tarnkappen. Von ihnen ist in diesem Buch die Rede - nicht ohne einen Blick aber auch auf jene Entwicklungen zu werfen, die Trendwenden zu mehr Lebensschutz signalisieren.

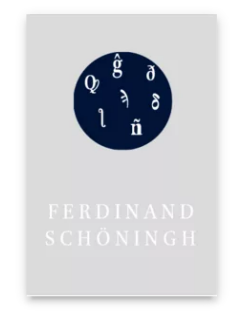

Published: 19

Jan 2011

Pages: 258

Seiten

Subjects:

General,

Theology and

World

Christianity

Publisher: Brill |

Schöningh

E-Book (PDF)

ISBN: $978-3^{-}$

657-72949-4

Paperback

ISBN: 978-3-

506-72949-1

Price:

[US. \$52.00 
Biographical Note

Manfred Spieker, Prof. Dr. phil., ist em. Professor für Christliche Sozialwissenschaften an der Universität Osnabrück.

Please send your order to: Brockhaus/Commission Tel: +49(o)71 541327 9216 | E-Mail: brill@brocom.de

For questions please contact: Brill Deutschland GmbH

Wollmarktstraße 115 | 33098 Paderborn | Germany

Tel: +49 (o)5251 69975 o | E-Mail: sales@brill.com. 